\title{
Causes and Costs of Financial Inclusion in India
}

\author{
Dr. Sweta Goel (Corresponding Author) \\ Assistant Professor, Amity College of Commerce and Finance \\ Amity University, Noida \\ E-mail: goel.sweta@yahoo.co.in
}

Mr. Amit Goel

Assistant Vice President

Royal Bank of Scotland, Gurgaon

E-mail: amitgoel_2k@yahoo.com

Received: Nov. 30, 2018

Accepted: Jan. 9, 2019

Published: January 9, 2019

doi:10.5296/jmr.v11i1.14192

URL: https://doi.org/10.5296/jmr.v11i1.14192

\begin{abstract}
The growth of the economy is dependent on the inclusive growth of all the parts of the country, be it rural or urban. The availability of quality financial product and services is extremely important for the growth of the economy. Therefore greater financial inclusion in poorer and bottom of the pyramid segments is imperative. Financial inclusion can lead to equitable and inclusive growth of the nation. Therefore, it is a high agenda for Government of India and Reserve Bank of India. The present study focuses on understanding and analyzing the extent of financial inclusion on the basis of its indicators. Therefore, we examine the key issues in financial inclusion/ exclusion and discuss the conceptual framework and issues related to the measurement of financial exclusion. The extent causes and costs of financial exclusion are conferred and some suggestions for improving the state of financial inclusion are given.
\end{abstract}

Keywords: Financial inclusion, financial exclusion, indicators, dimensions, Reserve Bank of India, sources of credit, condition exclusion, access exclusion, self-exclusion and price exclusion 


\section{Introduction}

"The test of our progress is not whether we add more to the abundance of those who have much; it is whether we provide enough for those who have too little."

\section{- Franklin D. Roosevelt}

Mahatma Gandhi said, "Poverty is the worst form of violence". For reducing income disparities and poverty and accelerating the growth, an access to tranquil, safe and affordable credit and other financial services by the poor and vulnerable groups, disadvantaged areas and lagging sectors of the society is indispensable. Importance of access to finance as a crucial poverty alleviation tool is the broad international consensus today. Despite it, globally more than two billion people are excluded from access to financial services (United Nations, 2006a). In most developing countries, due to non - availability of financial services, a large segment of society depends on informal sources of finance. This comes at an unreasonably high cost. In least developed countries (LDCs), situation is even shoddier with more than 90 per cent of the population excluded from access to the formal financial system (United Nations, 2006a).

Financial inclusion is promoted as one of the important national objectives of the country. Eleventh Five-Year Plan re-emphasized the need for a more inclusive growth and ensured a broad-based per capita income growth. Since 2005, one of the major agendas of Reserve Bank of India is to bring the large population within the structured and organized financial system (Mohan, 2006). Some major efforts and initiatives to reach the large sections of the hitherto financially excluded population have been taken by the Government of India and the Reserve Bank of India in the last five decades. These include the nationalization of banks, setting up of vigorous branch network of scheduled commercial banks, co-operatives and regional rural banks, starting the mandated priority sector lending targets, lead bank scheme, establishment of self-help groups, authorizing banks to appoint Business Correspondents (BC) or Business Facilitator (BF) to provide door step delivery of banking services, zero balance Basic Saving Bank Deposit (BSBD) accounts, etc.

The present study attempts to understand and analyze the extent of financial inclusion on the basis of its indicators. After examining the key issue in financial inclusion/ exclusion in the current section, second section discusses the conceptual framework and issues related to the measurement of financial exclusion. In section three, the extent, causes and costs of financial exclusion are discussed and in section four we conclude.

\section{Literature Review}

Conceptual framework- access to finance

Defining financial inclusion is a critical factor for developing a conceptual framework and identifying the factors that lead to low level of access to the financial system. There is no universally accepted definition of financial inclusion as its measurement is perceived to be difficult. It is mostly defined in terms of exclusion from the financial system. In early discussions, the financial exclusion was heralded by social exclusion. It was focused primarily on the issue of geographical access to financial services, specifically the banking 


\section{Macrothink}

outlets (Leyshon and Thrift, 1993). The argument has widened, and it includes the people who make little or no use of financial services and the progressions of financial exclusion (Ford and Rowlingson, 1996; Kempson and Whyley, 1998).

In the literature, definition of financial exclusion varies on the basis of three dimensions as 'breadth', 'focus' and 'degree' (figure. i). Broadest dimension is 'breadth' that preclude poor and disadvantaged from acquiring access to the financial system (Leyshon and Thrift, 1995). The potential difficulties encountered by some sectors in retrieving conventional financial services such as bank accounts, home insurance etc. fall under 'focus' dimension (Meadows et al., 2004). The 'degree' dimension, narrowest of all definitions of financial exclusion defines it as exclusion from particular sources of credit and other financial services such as bill-payment services, insurance and accessible deposit accounts (Rogaly, 1999). This line of thinking defines financial exclusion as emanating from increased inclusion leaving behind the minority of individuals and households (Kempson et al., 2000). Table i depicts some of the definitions of financial inclusion/ exclusion that have been evolved over the past several years.

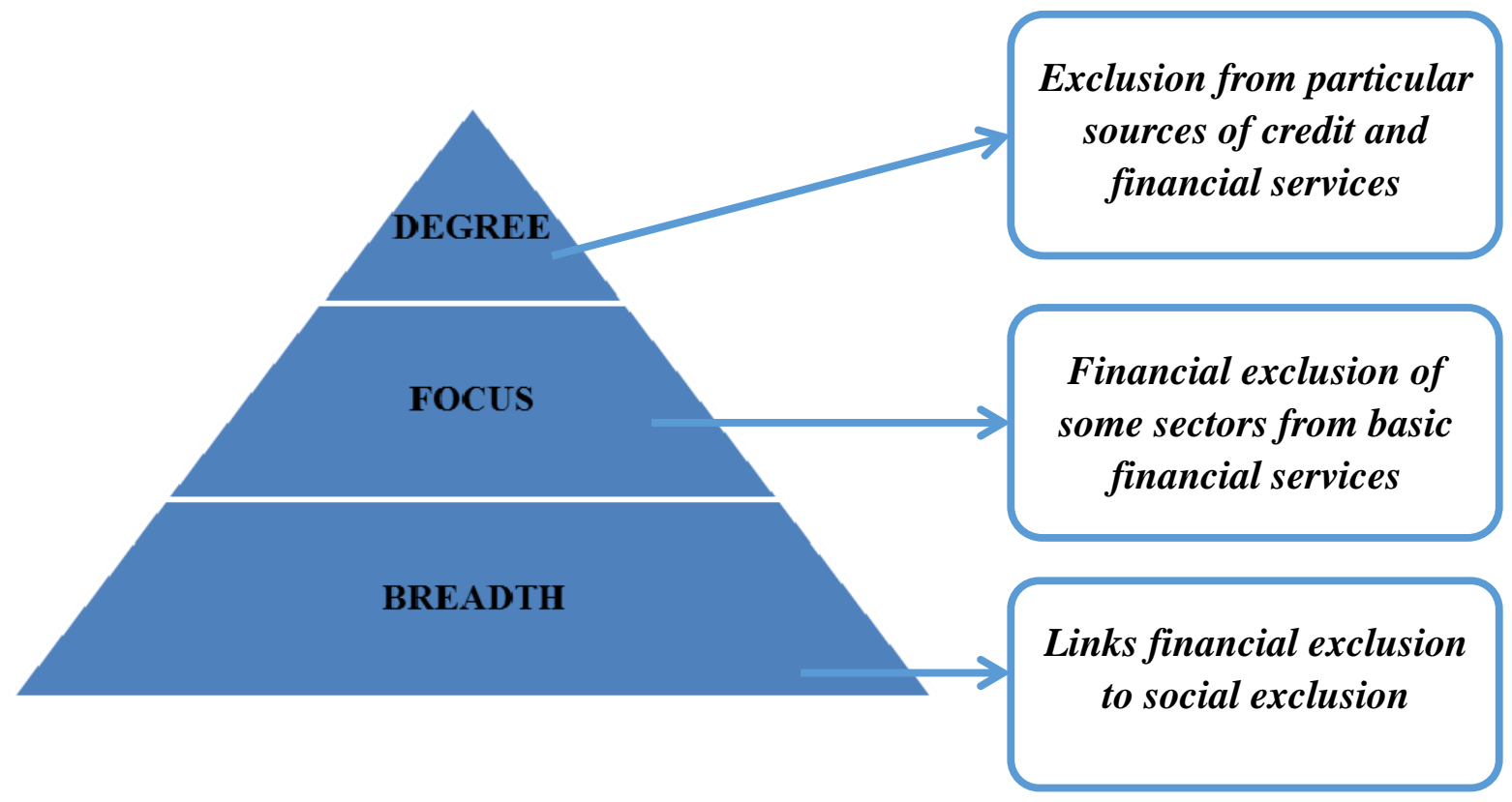

Figure 1. Dimensions of Financial Exclusion

Source: Researcher's literature review 


\section{MInstitute Macrothink}

Table i. Financial inclusion/ exclusion- Definitional aspect

Institution/ Author: Definition

ADB (2000): "Wide range of financial services accessible to poor and low-income groups as

1 well as their micro enterprises."

Indicators: Deposits, payment services, money transfer, loans and insurance

Stephen P. Sinclair (2001): "Financial exclusion is the inability to access basic financial

services. This may be because of the access, prices, conditions, and marketing or

2 self-exclusion problems."

Indicators: Basic banking services such as credit, insurance, money transmission, debt, long term savings and financial literacy.

Chant Link and Associates, Australia (2004): "Financial exclusion is the dearth of access

by certain consumers to suitable fair, low cost and safe financial services and products from

3 mainstream providers."

Indicators: Direct investment and deposit accounts, credit cards, personal loan, home loan, home and building insurance.

Treasury Committee, House of commons, U.K. (2004): "Financial inclusion is the ability

4 to access appropriate financial services and products."

Indicators: Affordable credit and suitable savings with access to financial advice.

Scottish Government (2002): "Financial inclusion means an access to financial services and products along with the knowledge, skills, capacity and understanding to make the best use

5 of those services and products."

Indicators: Access to financial services and products with the knowledge, skills, capacity and understanding.

United Nations (2006 b): "Financial inclusion means a financial sector providing 'access' to

6 insurance for all insurable people and firm, to credit for all bankable people and firms and to payment services and savings for everyone.

Indicators: Access to insurance, credit, payment services and savings.

Report of the Committee on Financial Inclusion in India; Chairman: C Rangarajan (2008): "Financial Inclusion means ensuring access to financial services with adequate and

7 timely credit at an affordable cost by vulnerable groups such as low income groups and weaker section of the society."

Indicators: Access to financial services with adequate and timely credit.

World Bank (2008): "Financial inclusion that is a broad access to financial services implies

8 and absence of price and non- price barriers in the use of financial services."

Indicators: Access to financial services such as payment, deposit, insurance and credit.

Report of the Committee on Financial Sector Reforms (Chairman: Dr. Raghuram

Rajan) (2009): "Financial Inclusion is the universal access to a wide range of financial services at a reasonable cost that include banking products and other financial services such

9 as insurance and equity products"

Indicators: Household access to financial services as contingency planning (retirement and buffer savings and insurable contingencies), credit (business livelihood and emergency, housing and consumption loans) and wealth creation (savings and investments) 


\section{Macrothink}

Source: Researcher's literature review

\section{Methodology}

\subsection{Indicators of Financial Inclusion}

Financial inclusion helps in expanding the resource base of the financial system and plays its own role for economic development. Further, it brings low income groups within the boundary of formal banking sector and thus protects their financial wealth and other resources. The importance of financial inclusion has been widely accepted. However, a review of past literature reveals that a comprehensive measure to indicate the extent of financial inclusion across countries is still lacking. Various indicators are available for measuring the depth of capital markets, banking system and insurance sector but less information is available for the degree of financial inclusiveness. Two types of indicators are used for measuring the financial inclusion (figure. ii). The first indicator is individual indicator' that provides only partial information on the level of financial inclusion in an economy. The second indicator is 'financial services and products' that form the basis for measuring the financial inclusion.

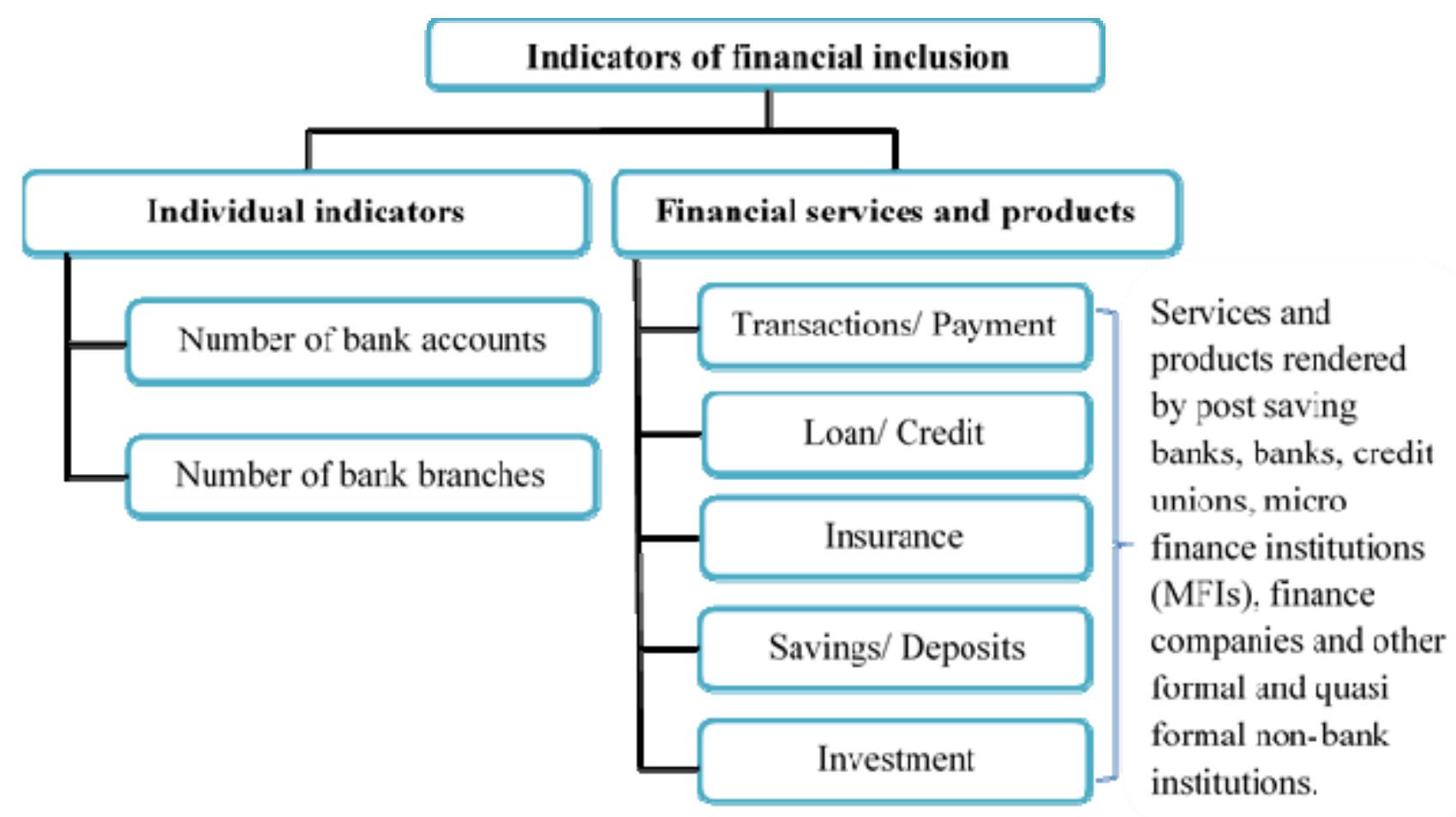

Figure ii. Indicators for measuring the extent of financial inclusion

Source: Literature review by the researcher 


\section{Macrothink}

Based upon the core indicators, population can be divided into four segments regarding the access to finance. These are the proportion of population using services from bank or bank likes institutions, using services of non-bank other formal financial institutions, informal financial services providers only and lastly, no financial services at all.

\subsection{Extent, Causes and Cost Of Financial Exclusion}

\section{Extent of financial exclusion}

Financial exclusion is the major cause of the lack in financial inclusion. The extent of financial exclusion from different angularities (based upon the five different data sources) is discussed further in detail.

\section{i. NSSO $59^{\text {th }}$ Round Survey Results (Note 1)}

Formal sources of credit are not available to the $73 \%$ of farmer households. $51.4 \%$ of farmer households are financially excluded from both formal and informal sources. Financial exclusion is more acute in Central, Eastern and North-Eastern regions that retain $64 \%$ of all financially excluded farmer households in the country. Indebtedness to formal sources of finance of these three regions miserably accounted for only $19.66 \%$. However, as shown in chart $\mathrm{i}$, over the period of five decades, there is an escalation in the access to formal sources (Note 2) credit by rural household. On the other hand, these households have lessened the use of informal sources of finance.

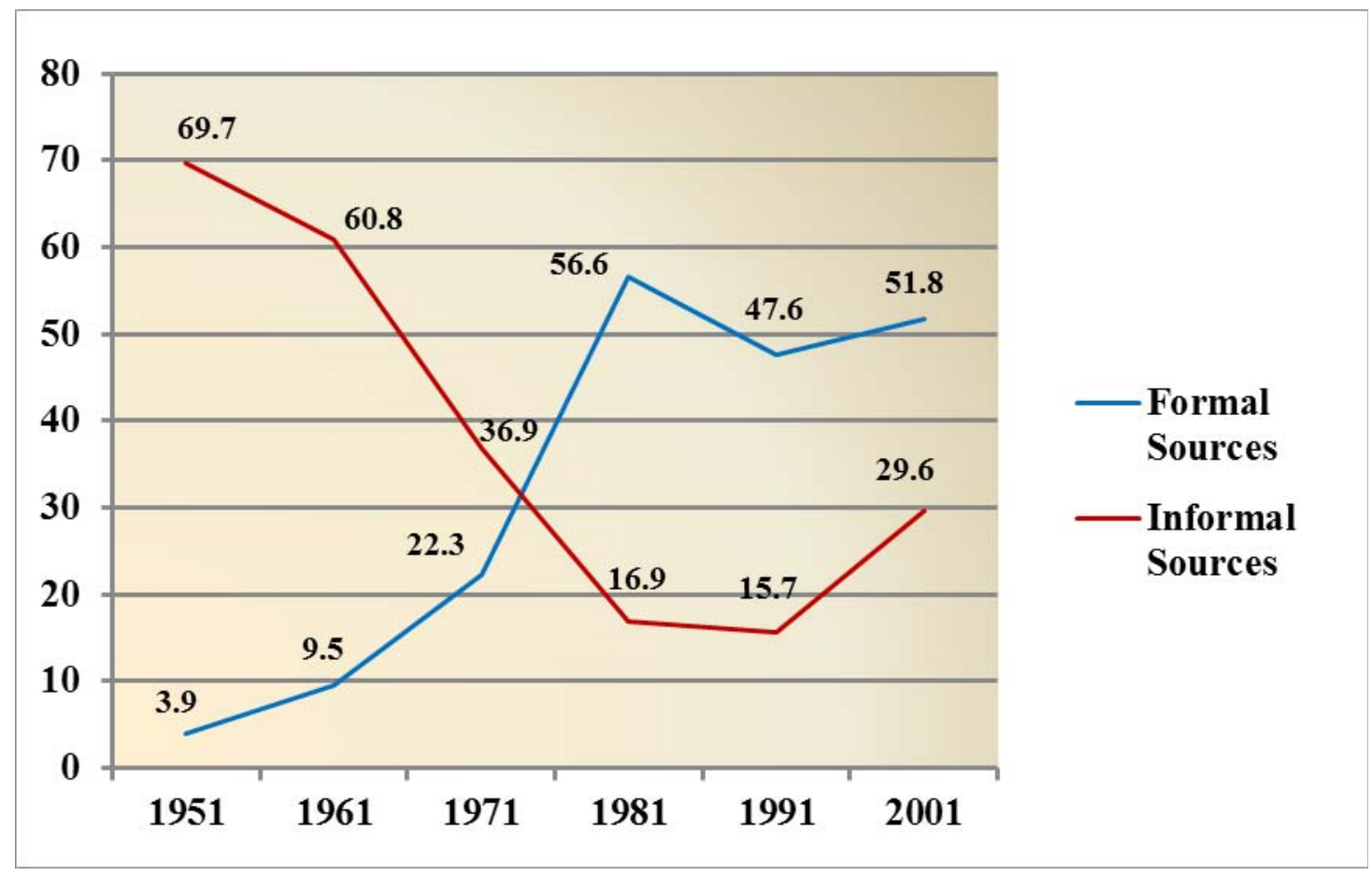

Chart i: Access to Formal and Informal Sources of credit by rural households

Source: RBI working paper $05 / 2013$ 


\section{1) Macrothink}

\section{ii. Government of India Population Census 2011}

From Census 2011, it was revealed that only $58.7 \%$ of households in the country are availing banking services. In spite of the low percent as only 58.7, it shows a significant rise in availing of baking services during last decade. Growth in the use of banking services from 2011 to 2001 is largely on account of increase in banking services in rural areas (Chart ii).

\section{iii. CRISIL Financial Inclusion Index (Inclusix)}

In June 2013, first comprehensive financial inclusion index (that is Inclusix) was published by CRISIL. The index was constructed using three critical parameters of basic banking services. The first is branch penetration measured as the number of bank branches per one lakh population. Second is Deposit penetration that is the number of saving deposits account per one lakh population. Third parameter is Credit penetration is calculated by taking the average of three measures namely number of loan accounts per one lakh population, number of small borrower loan accounts per one lakh population and number of agriculture advances per one lakh population. This index indicates an overall improvement in financial inclusion in India (Chart iii). CRISIL -Inclusix rose from 35.4 in March 2009 to 37.6 in March 2010 and 40.1 in March 2011 (on a scale of 100).

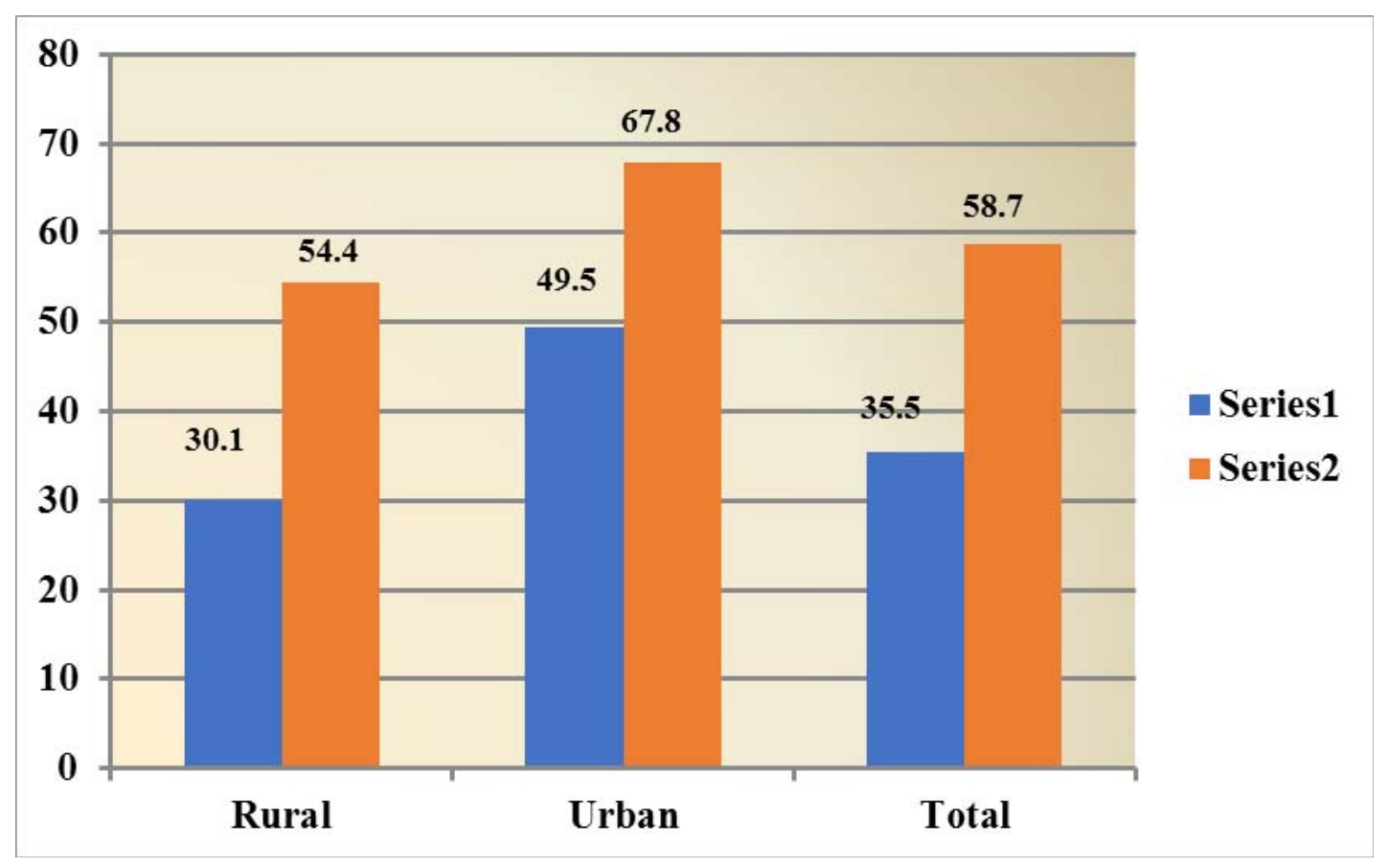

Chart ii: Availing of Banking Services

Source: Department of Financial Services, GOI

Note: Series 1 represent the census 2001 and series 2 represents the census 2011 


\section{Macrothink}

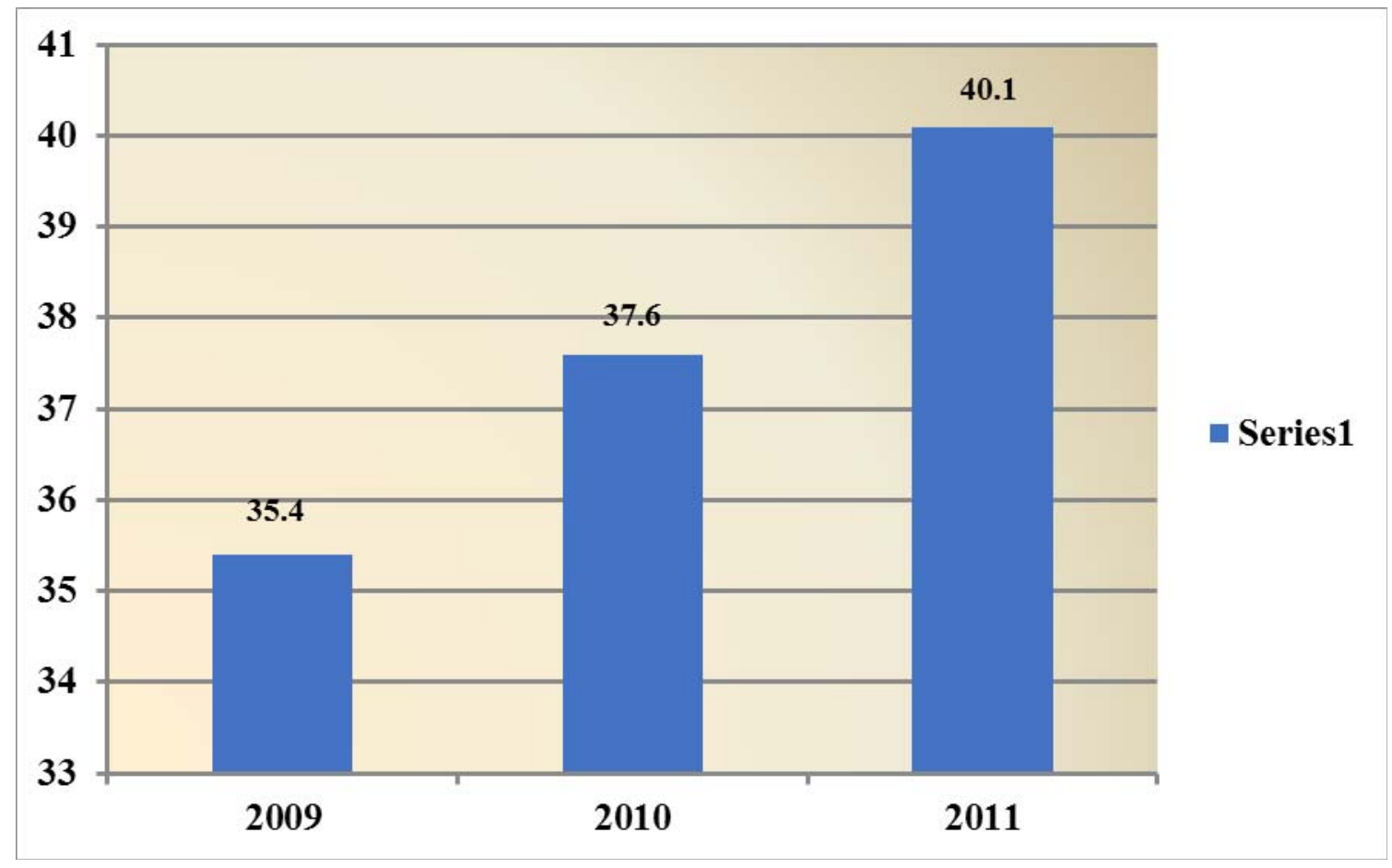

Chart iii. CRISIL - Inclusix

\section{iv. RBI Working Paper Study}

Sadhan Kumar (2011) worked out an Index on financial inclusion (IFI) based on three variables. First is the 'availability of banking services' that is number of bank branches available per 1000 population. Second is 'penetration' that is number of adult population having bank account and the third is 'usage' which is measured as outstanding credit and deposit. IFI was measured on a scale from 0 to 1 where 0 means very poor financial inclusion and 1 indicates high financial inclusion. The results indicate that Maharashtra, Kerala and Karnataka states have achieved high financial inclusion (IFI $>0.5$ ), while Tamil Nadu, Punjab, Andhra Pradesh, Himanchal Pradesh, Sikkim, and Haryana identified as a group of medium financial inclusion $(0.3<$ IFI $<0.5)$. The remaining states have very low financial inclusion.

\section{v. World Bank 'Financial Access Survey' Results}

In India financial exclusion measured in terms of ATM density, bank branch density, bank deposits to GDP and bank credit to GDP is quite low as compared with most of developing countries in the world (table ii). 
Table ii. Select Indicators of Financial Inclusion, 2011

\begin{tabular}{|c|l|c|c|c|c|c|c|}
\hline S.No. & Country & $\begin{array}{c}\text { Number of } \\
\text { Bank } \\
\text { Branches }\end{array}$ & $\begin{array}{c}\text { Number } \\
\text { of } \\
\text { ATMs }\end{array}$ & $\begin{array}{c}\text { Number } \\
\text { of Bank } \\
\text { Branches }\end{array}$ & $\begin{array}{c}\text { Number } \\
\text { of ATMs }\end{array}$ & $\begin{array}{c}\text { Bank } \\
\text { Deposits }\end{array}$ & $\begin{array}{c}\text { Bank } \\
\text { Credit }\end{array}$ \\
\cline { 3 - 8 } & $\begin{array}{c}\text { Per 0.1 } \\
\text { Million }\end{array}$ & \multicolumn{3}{|c|}{ Per 1000 KM } & \multicolumn{2}{|c|}{ As \% of GDP } \\
\hline 1 & India & 10.64 & 8.9 & 30.43 & 25.43 & 68.43 & 51.75 \\
\hline 2 & China & 23.81 & 49.56 & 1428.98 & 2975.05 & 433.96 & 287.89 \\
\hline 3 & Brazil & 46.15 & 119.63 & 7.93 & 20.55 & 53.26 & 40.28 \\
\hline 4 & Indonesia & 8.52 & 16.47 & 8.23 & 15.91 & 43.36 & 34.25 \\
\hline 5 & Korea & 18.8 & --- & 79.07 & -- & 80.82 & 90.65 \\
\hline 6 & Mauritius & 21.29 & 42.78 & 104.93 & 210.84 & 170.7 & 77.82 \\
\hline 7 & Mexico & 14.86 & 45.77 & 6.15 & 18.94 & 22.65 & 18.81 \\
\hline 8 & Philippines & 8.07 & 17.7 & 16.29 & 35.75 & 41.93 & 21.39 \\
\hline 9 & South Africa & 10.71 & 60.01 & 3.08 & 17.26 & 45.86 & 74.45 \\
\hline 10 & Shi Lanka & 16.73 & 14.29 & 41.81 & 35.72 & 45.72 & 42.64 \\
\hline 11 & Thailand & 11.29 & 77.95 & 12.14 & 83.8 & 78.79 & 95.37 \\
\hline 12 & Malaysia & 10.49 & 56.43 & 6.32 & 33.98 & 130.82 & 104.23 \\
\hline 13 & UK & 24.87 & 122.77 & 52.87 & 260.97 & 406.54 & 445.86 \\
\hline 14 & USA & 35.43 & --- & 9.58 & --- & 57.78 & 46.83 \\
\hline 15 & Switzerland & 50.97 & 100.39 & 84.53 & 166.48 & 151.82 & 173.26 \\
\hline 16 & France & 41.58 & 109.8 & 40.22 & 106.22 & 34.77 & 42.85 \\
\hline
\end{tabular}

Source: Financial Access Survey, IMF; Figures in respect of UK are as on 2010

\section{Results and Discussion}

\section{Causes of Financial Exclusion}

Theories of development advocate that financial development leads to growth through either a 'supply leading' or a 'demand following' channel. In the former channel, financial development spurs growth and in the later one, growth generates demand for the financial products.

Many supply side factors as geographical access or branch location, price of products and services offered and penetration or usage of services are responsible for the financial exclusion. It may also be a result of a variety of structural factors such as stringent documentation and collateral requirements, unavailability of products suiting the requirements of customers and increased competition in financial services (United Nations $2006 \mathrm{~b}$ ). Apart from the above discussed supply side factors, demand side factors also bear a significant role in the extent of financial exclusion. A higher proportion of population below the poverty line results in a low demand for financial products and services particularly 


\section{Mll Macrothink}

Journal of Management Research

ISSN 1941-899X 2019, Vol. 11, No. 1

savings products. From literature review various other factors affecting the access of financial services are revealed and summarized in table iii.

Table iii. Factors affecting the access to Financial Services

\begin{tabular}{|c|c|}
\hline Factor & Explanation \\
\hline Gender issues & $\begin{array}{l}\text { Access to credit is often limited to women who do not possess the title of land or } \\
\text { property. }\end{array}$ \\
\hline Age factor & $\begin{array}{l}\text { Financial services and products are typically designed for the economically } \\
\text { active middle aged population. Older and younger potential customers are often } \\
\text { overlooked. }\end{array}$ \\
\hline Legal identity & $\begin{array}{l}\text { Ethnic minorities, women, migrant workers and economic and political refugees } \\
\text { are often excluded from financial services because of the lack of legal identities } \\
\text { like birth certificates or identity cards. }\end{array}$ \\
\hline $\begin{array}{l}\text { Limited } \\
\text { literacy }\end{array}$ & $\begin{array}{l}\text { Limited literacy that is business finance skills, basic mathematics and lack of } \\
\text { understanding the procedures often restrain the demand for financial products. }\end{array}$ \\
\hline Place of living & $\begin{array}{l}\text { Rural and remote areas, density of population, insurgency in a location, mobility } \\
\text { of the population i.e., highly mobile people with no fixed or formal address also } \\
\text { affect access to financial services. }\end{array}$ \\
\hline $\begin{array}{l}\text { Psychological } \\
\text { and cultural } \\
\text { barriers }\end{array}$ & $\begin{array}{l}\text { Sometimes people particularly from low income groups decide not to opt for a } \\
\text { financial product because of the fear of refusal to access by the service providers. }\end{array}$ \\
\hline $\begin{array}{l}\text { Social security } \\
\text { payments }\end{array}$ & $\begin{array}{l}\text { Banking inclusion much higher in the countries where payment to social security } \\
\text { is not linked to the banking system. }\end{array}$ \\
\hline Bank charges & $\begin{array}{l}\text { A range of charges on banking transactions create a disproportionate effect on } \\
\text { low income group people. }\end{array}$ \\
\hline $\begin{array}{l}\text { Terms and } \\
\text { conditions }\end{array}$ & $\begin{array}{l}\text { Several terms and conditions associated with the use of financial products and } \\
\text { services such as minimum balance required etc. often dissuade people from their } \\
\text { use. }\end{array}$ \\
\hline $\begin{array}{l}\text { Level of } \\
\text { income }\end{array}$ & $\begin{array}{l}\text { Income discrimination and perception barriers among potential investors in } \\
\text { group lending programs may exclude poorer members of the community even } \\
\text { when the services are tailored for them. }\end{array}$ \\
\hline $\begin{array}{l}\text { Type of } \\
\text { occupation }\end{array}$ & $\begin{array}{l}\text { Sometimes the loan application of small borrowers and unorganized enterprises } \\
\text { are not evaluated and hence are rejected. }\end{array}$ \\
\hline $\begin{array}{l}\text { Attractiveness } \\
\text { of the product }\end{array}$ & $\begin{array}{l}\text { Two crucial aspects in financial inclusion are type of financial services and } \\
\text { products and the manner in which their availability is marketed. }\end{array}$ \\
\hline
\end{tabular}

Source: World Bank 2008, Asian Development Bank 2007 and Kempson et al., 2004

\section{Costs of Financial Exclusion}

The issue of the cost of financial inclusion might be comprehended from two intertwined angles. 
First is the cost that exclusion causes for entities or individuals in terms of loss of opportunities to grow because of the absence of access to finance or credit. It leads to higher charges for basic financial transactions like transfer of money and credit, besides all round impediments in basic transactions for day to day living. It could also lead to denial of access to better products or services that may require a bank account. There is inherent risk in holding and storing money as individuals operate solely on a cash basis. In this manner, Individuals and families might get sucked into a cycle of poverty and exclusion. This leads them to high cost credit from moneylenders, resulting in greater financial strain and unmanageable debt. More insightful outcome of financial exclusion include cost and security issues in dealing with cash flow and payments, compromised standard of living resulting from the deficiency of access to short-term credit and costly informal credit), acquaintance to uninsured risks, extended dependence on welfare rather than savings and increased exposure to unprincipled, greedy and unregulated providers (Chant Link and Associates, 2004). Financial exclusion obfuscates day-to-day cash flow management as the households and micro and small enterprises deal entirely in cash and are vulnerable to irregular cash flows. Furthermore, it leads to the lack of financial security and planning.

Second is the cost caused by financial exclusion from the societal or national standpoint. The country may not realize its aggregate potential because of the aggregate loss of output or welfare caused by the financial exclusion. At the wider level of the society and the nation, it leads to poverty, social exclusion and all other related economic and social problems. Thus, financial exclusion is often an indicator as well as a cause of poverty. It is not evenly distributed throughout society and is concentrated among the most disadvantaged communities and groups. As a result it leads to a much wider problem of social exclusion. Another cost of financial exclusion is faced by the banks in the terms of loss of business opportunity, particularly in the medium-term. For lending the services to lower income groups, banks have to inculcate initial cost of expanding their coverage that might exceed the revenue generated from such operations.

Therefore, the extent and causes of financial exclusion are varied in nature and no single factor could explain the phenomenon. The critical dimensions of financial exclusion comprise of the condition exclusion (that is conditions attached for availing the financial products and services), access exclusion, price exclusion and self-exclusion (that is a fear of refusal to access financial products and services by the service providers).

\section{Conclusion}

Notwithstanding the widely recognized importance of financial inclusion, its measure is perceived to be difficult and no universally accepted definition for it is available. Therefore, financial inclusion is often defined in terms of exclusion from the financial system. Two approaches can be followed to indicate the extent of financial inclusion/ exclusion. The first one is specific indicators such as number of bank branches, number of bank accounts that provides only partial information. The second approach is highly economy precise and it looks at details on the use of specific financial products and services. 
The most visible aspect of financial exclusion is that most of the low income groups are deprived from availing the most basic financial services. Some of the principal barriers in the expansion of financial services are demand side factors as high charges and penalties, conditions attached to the financial products and services that make them complicated or inappropriate, physical access and perception that financial services institutions are unwelcoming to the lower income group. Socio-cultural factors also matter to an individual to access financial services. Therefore, the critical dimension of financial exclusion includes condition exclusion, access exclusion, self-exclusion and price exclusion. The supply side factors are also responsible for the extent of financial exclusion. For instance, low level of income and hence lower savings lessens the deposits and borrowing capacity of the individuals. Both the demand and supply side factors have an important bearing on the usage of financial and banking products and services.

The matter of cost or consequences of financial exclusion has been perceived from two perspectives. First, is the cost endured by individuals or entities as they tend to lose various growth opportunities because of the non-availability of credit and finance. Second cost is from the societal or national perspective. Financial exclusion hinders the growth potential of the country as it leads to aggregated loss of output or welfare.

\section{Scope for Further Research}

Realizing the explicit and implicit cost of financial exclusion, Reserve Bank of India and Government of India has initiated measures to deal with the same. Efforts are taken and policies are framed out to bring the weaker and poorer section of the society with in the fold of formal banking system. Further study on the remedies and measures to be taken by the Reserve Bank of India and the Government of India will complement the existing literature on this issue. The need of the hour is to invent the most appropriate delivery model for different geographical regions given their unique characteristics.

The unbanked segments from rural, urban or metropolitan areas are largely served by the un-organized sector even today. Research into the products, practices and procedures of this unorganized sectors an absolute imperative, to identify and understand the same which the bottom of the pyramid populace finds so convenient and comfortable to deal with. This could throw up valuable leads for the organized sector - banks and financial institutions to follow.

\section{Notes}

Note 1.dia Debt and Investment Survey, NSSO 59th Round

Note 2. sources include credit from SCBs (including RRBs) and credit from Co - op society/bank and informal sources include credit from agricultural and professional money lenders.

\section{References}

Chant Link and Associates. (2004). A report on financial exclusion in Australia. Melbourne: ANZ. 


\section{Macrothink}

Journal of Management Research

ISSN 1941-899X 2019, Vol. 11, No. 1

Creado, J., \& Koshi, R. (2008). Creating Leaders at the Bottom of Pyramid. Microfinance Insight, Focus on human Resources: Finding the way to HR Challenge, 6.

Ford, J., \& Rowlingson, K. (1996). Low-Income Households and Credit: Exclusion, Preference, and Inclusion. Environment and Planning A, 28(8), 1345-1360. https://doi.org/10.1068/a281345

Kamath, \& Raghav. (2007). Branchless Banking: Corp Bank's Answer for Financial Inclusion. CAB Calling, 31(3).

Kempson, E., \& Whyley, C. (1998). Access to current accounts. London: British Bankers Association.

Kempson, E. at al. (2000). In or Out? Financial Exclusion: A Literature and Research Review. Consumer Policy and Research. Financial Services Authority, London.

Leyshon, A., \&Thrift, N. (1993). The Restructuring of the UK Financial Services in the 1990s. Journal of Rural Studies, 9, 223-241. https://doi.org/10.1016/0743-0167(93)90068-U

Leyshon, A. and Thrift, N. (1995). Geographies of financial exclusion: financial abandonment in Britain and the United States. Transactions of the Institute of British Geographers, New Series, 20, 312-41.

Meadows, P., Ormerod, P., \& Cook, W. (2004). Social networks: their role in access to financial services in Britain. National Institute Economic Review, 189(1), 99-109. https://doi.org/10.1177/002795010418900110

Rangarajan, C. (2008). Report of the Committee on Financial Inclusion.

Raghuram Rajan, C. (2009). A Hundred Small Steps - Report of the Committee on Financial Sector Reforms.

Rajan, M.S.S. (2007). Replication of Financial Inclusion: Oppor tunities and Challenges Indian Bank Experience. CAB Calling July-September, 31(3).

Rogaly, B., Fisher, T., \& Mayo, E. (1999). Poverty, social exclusion and microfinance in Britain. London: Oxfam GB. https://doi.org/10.3362/9780855988326.001

Sadhan, K. C. (2011). RBI Working Paper Series (WPS (DEPR): 8/2011). 